\title{
First record of Herdmania momus (Ascidiacea: Pyuridae) from the central Mediterranean Sea
}

\author{
JULIAN EVANS ${ }^{1,2}$, JOSEPH A. BORG ${ }^{1}$ AND PATRICK J. SCHEMBRI ${ }^{1}$ \\ ${ }^{1}$ Department of Biology, University of Malta, Msida MSD2080, Malta, ${ }^{2}$ Marine Biology and Ecology Research Centre, \\ University of Plymouth, Plymouth, PL4 8AA, UK
}

\begin{abstract}
The solitary ascidian Herdmania momus, an Indo-Pacific species that has been introduced into the Mediterranean Sea via the Suez Canal during the past century, has so far been restricted to the Levantine region. Here we record $\mathrm{H}$. momus from the Maltese Islands, which represents a considerable westwards expansion of the species' distribution range in the Mediterranean. Possible modes of introduction are discussed, with translocation of adults via shipping and subsequent spawning at destination sites deemed a plausible mechanism.
\end{abstract}

Keywords: Chordata, Tunicata, Herdmania momus, Malta, alien species, range extension

Submitted 6 August 2013; accepted 24 October 2013

\section{INTRDロUCTIDN}

The solitary ascidian Herdmania momus (Savigny, 1816) is an Indo-Pacific species that has been introduced from the Red Sea into the Mediterranean via the Suez Canal (Shenkar \& Loya, 2008, 2009). It was first recorded in the Suez Canal in 1924 (Harant, 1927), while the first record of this species in the Mediterranean appears to be that by Harant (1939) from Alexandria, Egypt. Herdmania momus subsequently spread northwards (Zenetos et al., 2012), and has been recorded from Israel (Pérès, 1958), Lebanon (Monniot, 2002; Bitar et al., 2007), Cyprus (Monniot, 2002; Nishikawa, 2002) and Turkey (Çinar et al., 2006); however, all Mediterranean records have so far been restricted to the Levantine area (Izquierdo-Muñoz et al., 2009). Here we record $H$. momus from the Maltese Islands, which is the first report of the species from the central Mediterranean and which represents a considerable westwards expansion of the species' distribution range in this sea.

\section{MATERIALS AND METHDDS}

Individuals of Herdmania momus were first observed on the submerged vertical face of a concrete wharf in Marsaxlokk Bay, Malta, in June 2013. The identity of the species was confirmed based on spicule morphology (Figure 1). A survey was subsequently undertaken by snorkelling and SCUBA diving along the shore of Marsaxlokk harbour in order to map the distribution of the species, with searches focused at eight sites within the harbour (Figure 2). Since prior records of $H$. momus in the Mediterranean indicated that it occurs mainly on artificial structures, and is only rarely recorded from natural substrata (Shenkar \& Loya, 2008, 2009), most areas with artificial substrata present in Marsaxlokk were included in the survey (Sites A-F), except those forming part of the Malta Freeport, which were not accessible for security reasons. A high density of individuals was observed at Site F (see below), so an additional two sites ( $\mathrm{G}$ and $\mathrm{H}$ ) in close proximity to Site F, but where the bottom consists of a natural hard substratum, were also included in the survey. To estimate the density of H. momus at Site F, two stations ( $\mathrm{F}_{1}$ and $\mathrm{F}_{2}$; see Table 1) were established approximately $150 \mathrm{~m}$ apart and five $35 \times$ $35 \mathrm{~cm}$ quadrats were placed at random at a depth of $5 \mathrm{~m}$ at each station and photographed. The number of $H$. momus individuals per quadrat was subsequently counted from the photographs.

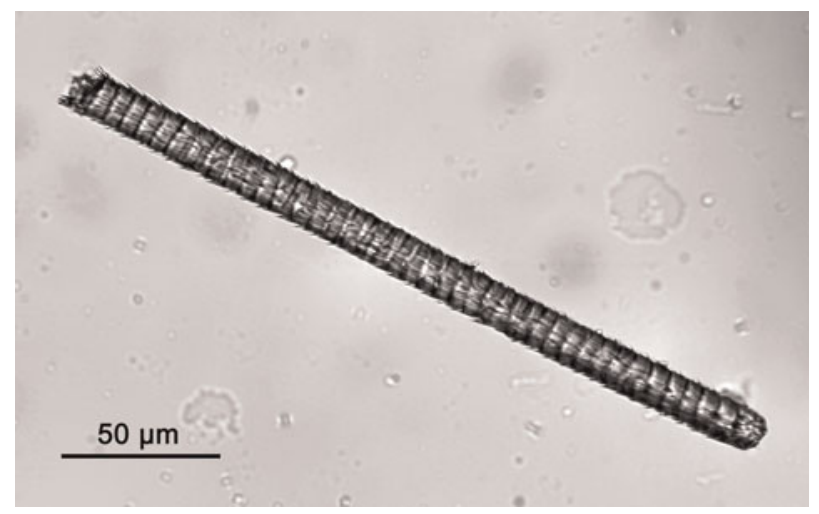

Fig. 1. Photomicrograph of a single spicule of Herdmania momus, obtained from an individual collected from Site F (see Figure 2). 


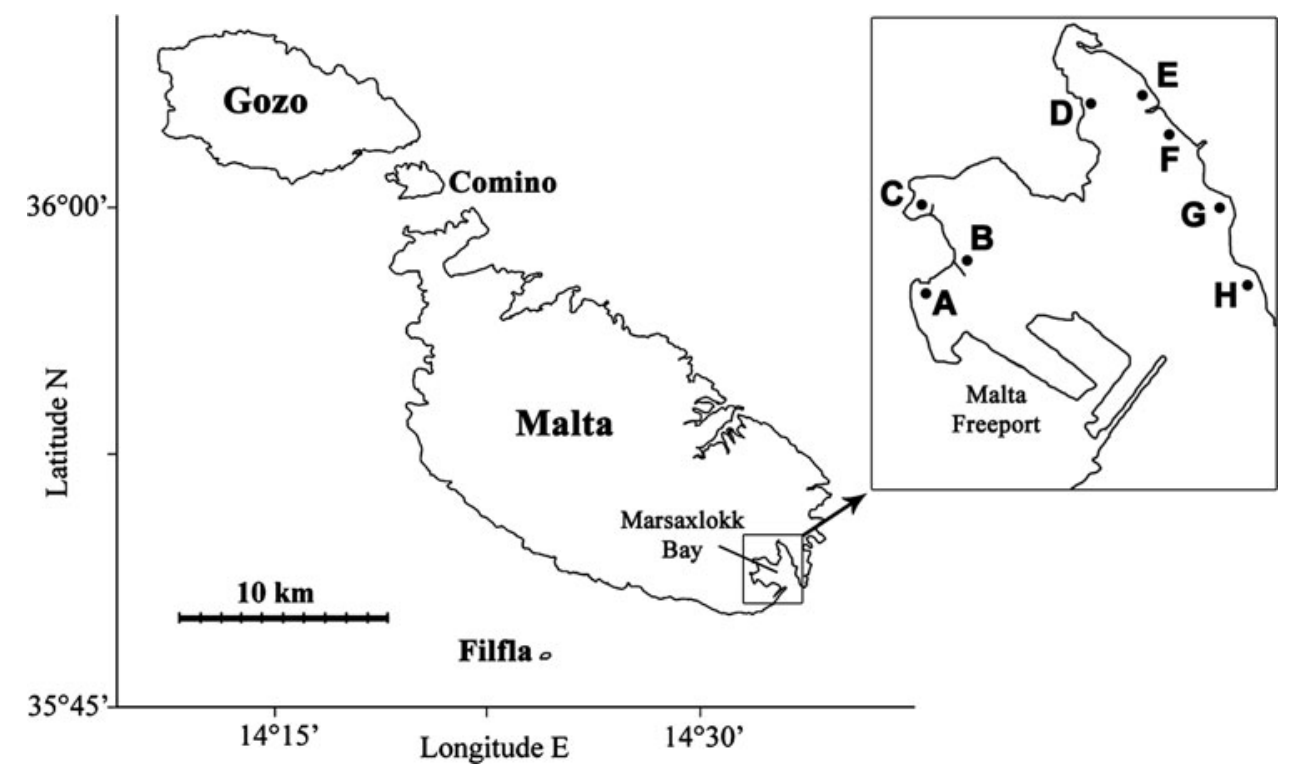

Fig. 2. Map of the Maltese Islands showing the location of Marsaxlokk Bay (enlarged in inset) and of the surveyed sites. Artificial substrata were present at Sites A-F, while Sites $\mathrm{G}$ and $\mathrm{H}$ had natural substrata.

\section{RESULTS}

Individuals of Herdmania momus were observed on the artificial substrata at Sites A, B, E and F, but not on those at Sites C and D or on the natural substrata at Sites $G$ and $\mathrm{H}$. Only a single individual of $H$. momus was observed along the jetty at Site B. At Sites A and E the shore consists of a concrete quay, and $H$. momus was present from a depth of $0.5 \mathrm{~m}$ down to the natural bottom at a depth of $\sim 2 \mathrm{~m}$. Individuals generally occurred in small aggregations of less than ten individuals, but large areas without any $H$. momus were also present such that the overall density of ascidians at these two sites was comparatively low. Furthermore, practically all of the $H$. momus recorded from Site E were present at the south-eastern end, close to Site F (from which Site $\mathrm{E}$ is separated by a small breakwater).

On the other hand, H. momus was very abundant at Site F (Figure 3). Here the shore consists of a vertical concrete wall that extends to a depth of $10 \mathrm{~m}$; this wharf serves for berthing ships that supply fuel to the nearby Delimara Power Station. Herdmania momus occurred along the entire length and depth range of the wall, except for the top $0.5 \mathrm{~m}$, with a population density ranging from a mean of 11.2 individuals per $35 \times 35 \mathrm{~cm}$ quadrat ( 91 ind. $\mathrm{m}^{-2}$ ) at Station $\mathrm{F} 2$, to 32.0 individuals per quadrat $\left(261\right.$ ind. $\mathrm{m}^{-2}$ ) at Station F1 (Table 1; see also Figure 3).

Table 1. Mean $( \pm \mathrm{SD})$ number of Herdmania momus individuals per $35 \times 35 \mathrm{~cm}$ quadrat $(\mathrm{N}=5)$ recorded from sampling stations $\mathrm{F}_{1}$ and $\mathrm{F} 2$, together with the respective geographical coordinates (WGS84 datum).

\begin{tabular}{lll}
\hline Station & $\begin{array}{l}\text { Coordinates } \\
\text { (latitude/longitude) }\end{array}$ & $\begin{array}{l}\text { Mean }( \pm \mathrm{SD}) \\
\text { H. } \text { momus } \text { per quadrat }\end{array}$ \\
\hline $\mathrm{F}_{1}$ & $35^{\circ} 50.006^{\prime} \mathrm{N} 14^{\circ} 33.197^{\prime} \mathrm{E}$ & $32.0 \pm 11.2$ \\
$\mathrm{~F} 2$ & $35^{\circ} 49.934^{\prime \prime} \mathrm{N} 14^{\circ} 33.261^{\prime} \mathrm{E}$ & $11.2 \pm 1.3$ \\
\hline
\end{tabular}

\section{DISCUSSIDN}

The present report of Herdmania momus from the Maltese Islands represents the first record of this species from the central Mediterranean area. Prior to this record, H. momus had only been recorded from the Levantine region within the Mediterranean Sea, with its previously known westernmost position being the 2001 record from Kas, Turkey by Çinar et al. (2006; see figure 1 in Izquierdo-Muñoz et al., 2009), which is some $1350 \mathrm{~km}$ distant from Malta. The present record therefore represents a considerable westwards expansion of the species' distribution range in the Mediterranean.

Herdmania momus may have reached the Maltese Islands via natural range expansion through establishment of new populations as a result of westwards dispersal of planktonic larvae. This would mean that intermediate populations which have not yet been discovered may exist between

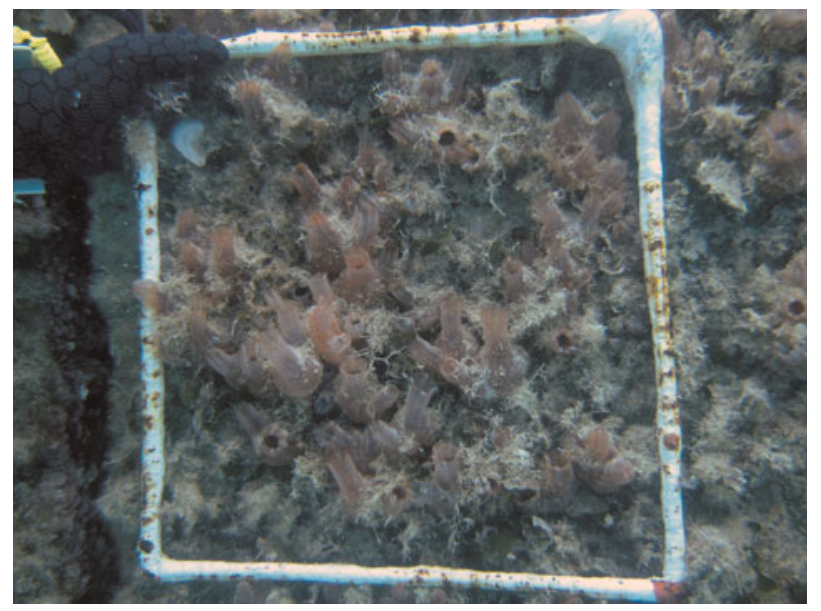

Fig. 3. Photograph of the vertical face of the concrete wharf at Site F (see Figure 2), showing one of the $35 \times 35 \mathrm{~cm}$ quadrats at Station $\mathrm{F}_{1}$ (see Table 1), and demonstrating the high density of Herdmania momus present. 
Turkey and Malta along the Aegean and Ionian coasts. However, it seems unlikely that any such populations would have gone unnoticed given that this ascidian is quite conspicuous due to its bright pink/red coloration and large size (maximum length $18 \mathrm{~cm}$; Shenkar \& Loya, 2008). Furthermore, it appears that $H$. momus reproduces only at a water temperature of $22-25^{\circ} \mathrm{C}$, which limits the reproductive period of the eastern Mediterranean populations to approximately two months a year (May-June and November), and this short reproductive period may limit the dispersal of the species (Shenkar \& Loya, 2008). It is also possible, although less likely given the general anticlockwise circulation of the Mediterranean surface water, that natural dispersal to the central Mediterranean may have occurred via the southern coast from Egypt, where $H$. momus is established at Alexandria (Izquierdo-Muñoz et al., 2009).

A more likely mechanism through which $H$. momus may have reached Malta is transport via shipping; this hypothesis is corroborated by the fact that Marsaxlokk is a busy commercial harbour and Site F, where the highest density of $H$. momus was recorded, is a regular berthing area for ships. Solitary ascidians can be transported by shipping in two main ways. Firstly, established adults attached to the hulls or to the interior surfaces of seawater-containing compartments such as sea chests or bow-thruster tunnels may spawn at a destination port; such spawning may even be triggered as a vessel travels from colder offshore water into the warmer water of a harbour. Secondly, planktonic eggs and larvae can be taken up together with ballast water from one port and subsequently discharged in another port while they are still viable (Davis et al., 2007).

In their discussion on possible mechanisms for the spread of the solitary ascidian Styela clavata, Davis et al. (2007) noted that transport of larvae via ballast water is only a plausible mechanism for very short journeys of up to 24 hours, as otherwise larvae would settle on the walls of the ballast tanks and probably fail to reach maturity given the limited water exchange in such tanks. On the other hand, they also commented that transport via ship hull fouling is unlikely based on hydrodynamic considerations that indicated that a $65 \mathrm{~mm}$ individual would have been removed by an 8 knot water flow within minutes. These authors suggested that transport of adults settled in sea chests and subsequent spawning at destination ports is a more plausible scenario, given that sea chests provide a sheltered environment with sufficient water exchange for growth and development. Since $H$. momus is of similar size to S. clavata and also has a short larval duration (Degnan et al., 1996), similar considerations apply to its potential translocation via shipping. It should also be noted that other marine traffic, apart from ships, may serve as a vector. Other such vectors include oil rigs, barges and fish cages that are towed at much slower speeds than that at which ships travel, and which may have as many, or more, sheltered marine compartments in which fouling organisms can survive long journeys.

According to Otero et al. (2013) H. momus can be a nuisance fouler on ships and man-made structures, but has not yet been shown to outcompete native species or invade natural ecosystems in the Mediterranean. In this respect, it is interesting to note that while $H$. momus has definitely become established in Malta, so far the recorded populations appear to be restricted to artificial substrata, similar to their Israeli counterparts (Shenkar \& Loya, 2008). However, seawater temperatures of $22-25^{\circ} \mathrm{C}$ are present for a longer duration in the central Mediterranean, which may result in an extended reproductive period for $H$. momus. Mean densities of this ascidian recorded from Site $\mathrm{F}$ during the present study (261 ind. $\mathrm{m}^{-2}$ at Station $\mathrm{F}_{1}$ ) were also higher than those recorded in Israel (maximum density: 71 ind. $\mathrm{m}^{-2}$ ). It remains to be seen whether these high densities have an ecological effect on the native biota present at the site, or if the high densities coupled with a longer reproductive period may result in a higher propagule pressure that will enable $H$. momus to eventually colonize natural substrata as well.

\section{ACKNDWLEDGEMENTS}

We are grateful to Alfonso A. Ramos-Esplá (Universidad de Alicante, Spain) for confirming the identity of the species. The research leading to these results has received partial funding from the European Community's Seventh Framework Programme (FP $7 / 2007-2013)$ under Grant Agreement No. 287844 for the project 'Towards COast to COast NETworks of marine protected areas (from the shore to the high and deep sea), coupled with sea-based wind energy potential' (COCONET). J.A. Borg was supported by a research grant awarded by the University of Malta.

\section{REFERENCES}

Bitar G., Ocaña O. and Ramos-Esplá A.A. (2007) Contribution of the Red Sea alien species to structuring some benthic biocenosis in the Lebanon Coast (Eastern Mediterranean). Rapport du Congrès de la Commission Internationale pour l'Exploration Scientifique de la Mer Méditerranée 38, 437-438.

Çinar M.E., Bilecenoglu M., Öztürk B. and Can A. (2006) New records of alien species on the Levantine coast of Turkey. Aquatic Invasions 1 , $84-90$.

Davis M.H., Lützen J. and Davis M.E. (2007) The spread of Styela clava Herdman, 1882 (Tunicata, Ascidiacea) in European waters. Aquatic Invasions 2, 378-390.

Degnan B.M., Rohde P.R. and Lavin M.F. (1996) Normal development and embryonic gene activity of the ascidian Herdmania momus. Marine and Freshwater Research 47, 543-551.

Harant H. (1927) Rapport sur les tuniciers. Transactions of the Zoological Society of London 22, 365-373.

Harant H. (1939) Les fonds de pêche près d'Alexandrie: Ascidiacea. Notes et Mémoires, Institut Fouad I Hydrobiologie et Pêche 28, 1-12.

Izquierdo-Muñoz A., Díaz-Valdés M. and Ramos-Esplá A.A. (2009) Recent non-indigenous ascidians in the Mediterranean Sea. Aquatic Invasions 4, 59-64.

Monniot C. (2002) Stolidobranch ascidians from the tropical western Indian Ocean. Zoological Journal of the Linnean Society 135, 65-120.

Nishikawa T. (2002) Revision of the ascidian genus Herdmania (Urochordata: Ascidiacea) inhabiting Japanese waters. Species Diversity 7, 217-250.

Otero M., Cebrian E., Francour P., Galil B. and Savini D. (2013) Monitoring marine invasive species in Mediterranean Marine Protected Areas (MPAs): a strategy and practical guide for managers. Malaga, Spain: IUCN. 
Pérès J.M. (1958) Ascidies récoltées sur les côtes méditerranéannes d'Israel. Bulletin of the Research Council of Israel 7B, 143-150.

Shenkar N. and Loya Y. (2008) The solitary ascidian Herdmania momus: native (Red Sea) versus non-indigenous (Mediterranean) populations. Biological Invasions 10, 1431-1439.

Shenkar N. and Loya Y. (2009) Non-indigenous ascidians along the Mediterranean coast of Israel. Marine Biodiversity Records 2, e166. doi: http://dx.doi.org/10.1017/S1755267209990753.

and

Zenetos A., Gofas S., Morri C., Rosso A., Violanti D., García Raso J.E., Çinar M.E., Almogi-Labin A., Ates A.S., Azzurro E., Ballesteros E., Bianchi C.N., Bilecenoglu M., Gambi M.C., Giangrande A., Gravili C., Hyams-Kaphzan O., Karachle P.K., Katsanevakis S., Lipej L.,
Mastrototaro F., Mineur F., Pancucci-Papadopoulou M.A., Ramos Esplá A., Salas C., San Martín G., Sfriso A., Streftaris N. and Verlaque M. (2012) Alien species in the Mediterranean Sea by 2012. A contribution to the application of European Union's Marine Strategy Framework Directive (MSFD). Part 2. Introduction trends and pathways. Mediterranean Marine Science 13, 328-352.

\section{Correspondence should be addressed to:}

J. Evans

Department of Biology

University of Malta

Msida MSD2080, Malta

email: julian.evans@um.edu.mt 